\title{
多重オルソフォト画像からの樹冠円抽出について
}

\section{Extraction of Circular Tree Crowns from Multiple Orthophoto Images}

\author{
井上 光平* - 瀬戸島政博** - 朝廣 和夫*** - 重松 敏則 $* * *$ \\ Kohei INOUE, Masahiro SETOJIMA, \\ Kazuo ASAHIRO and Toshinori SHIGEMATSU
}

\begin{abstract}
The spatial arrangement of the brightness values of remotely sensed imagery bears important information for forest canopy structures. This paper presents an algorithm to estimate tree crown size and position from color orthophoto images acquired at several seasons. The seasonal change in color of leaves gives us a piece of useful information about the boundary of neighboring tree crowns. The usefulness of the algorithm for practical applications is demonstrated with an experiment on multiple orthophoto images of the northern part of Kyushu Island.
\end{abstract}

\section{1.はじめに}

現在，持続的な国土環境の保全や自然資源を利用し た循環型社会の形成の場，二酸化炭素の吸収源の場と して, さらには, バイオマスエネルギーの宝庫として, 身近な里山の存在がクローズアップされ，その管理や 利活用が注目されている。里山は，人が長い間手を加 えることにより保全がなされ，利用性が增し，森林環 境が成り立ってきた場でもある。そこでは，さまざま な林相が形成され，地域独自の郷土景観を今日に残し ている。

多種多様な樹種が混ざり合って構成する里山の分布 を把握するには，植生の種類組成や構造などを基準と して分類した群集名や群落名で表現した植物社会学的 な区分よりも，樹林分布の全体的な外観（樹種·樹高·

* 九州大学大学院芸術工学研究院視覚情報部門

Faculty of Design, Kyushu University

** 国際航業株式会社技術センター

Kokusai Kogyo Co., Ltd.

下102-0085 東京都千代田区六番町 2 番地

***九州大学大学院芸術工学研究院環境計画部門

Faculty of Design, Kyushu University

「写真測量とリモートセンシング」VOL. 45，NO. 3， 2006
樹冠・立木密度等）を捉えた相観植生的な区分が必要 とされている(重松ら，1997）。このうち，森林の成長 過程や管理による森林構造の変化を把握するうえで, 樹冠の大小が重要なパラメータとなる(朝廣ら, 2003)。

これまで，森林の環境保全や森林資源の維持管理の ために，樹冠の大きさや分布などを定量的に計測する ことが求められている(小熊ら, 2000 ; Song \& Woodcock, 2003 ；朝廣ら，2003）。また，森林を構成する樹 冠の大きさと分布を定量的に計測する方法として，小 村ら（2003）は樹冠の形状を円で近似し，空撮画像か ら近似円を抽出する方法を提案した。この近似円をこ こでは「樹冠円」と呼ぶことにする。樹木は季節によっ て葉色が大きく変化するものがあり(瀬戸島ら， 2001， 2002，2005），この葉色変化の情報を利用すると樹冠円 の抽出精度を向上させることができると考えられる。

そこで, 本研究では, 複数の時期に撮影したカラー 航空オルソフォト画像（ここでは「多重オルソフォト 画像」と称する）を用いて樹冠円抽出の可能性を検討 することを目的とした。複数時期のカラ一航空オルソ 画像を用いることにより，季節による樹木の葉色変化 情報を樹冠の判別の要素に利用するとともに，細かな 陰影による樹冠の過分割（たとえば，1 時期の画像だ けでは，撮影の時間帯によっては樹冠内の枝葉による 細かな陰影が濃く写し出され, その陰影によって本来 


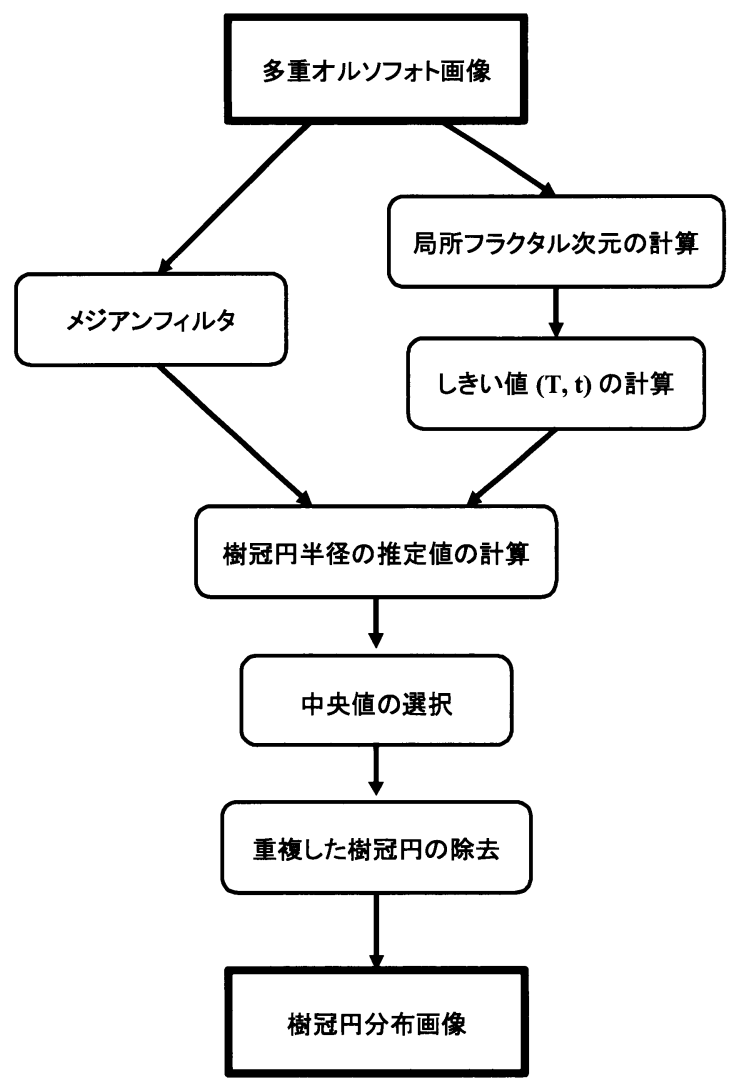

図 1 多重オルソフォト画像を用いた樹冠円の抽出手順

つつである樹冠が複数に分断されて抽出されてしまう ような恐れがある）の軽減に配慮した。

なお， 2 節では使用した多時期のカラ一航空写真と 多重オルソフォト画像の作成, 3 節では多重オルソ フォト画像から樹冠円を抽出する方法を提示し（図 1)，4節では, 多重オルソフォト画像を用いることに よって，1時期の画像だけを用いる場合よりも樹冠円 抽出の精度が向上することの検証結果を示す。 5 節で は，まとめと今後の課題等を述べる。

\section{2. 使用した多時期のカラー航空写真と多 重オルソフォト画像の作成}

本研究では，福岡市北東の古賀市谷山にある古賀夕 厶流域の里山を対象とし，1999年 4 月～2000年 2 月ま での 8 回にわたり撮影したカラ一航空写真（撮影縮尺 $1 / 10,000)$ を用いた。各時期の航空写真の比較照合が 容易になるように，各撮影日の天候は晴〜快晴，雲量 は 0.0 3.5 (平均雲量10分比) で, GPS 搭載の航空写
表 1 撮影時期とそのねらい

\begin{tabular}{|c|c|c|}
\hline 回数 & 撮影年月日 & 撮影のねらい \\
\hline 1 & 1999.04 .08 & サクラの開花・樹木の芽吹き時期 \\
\hline 2 & 1999.04 .27 & 常緑広葉樹・落葉広葉樹の新葉時期 \\
\hline 3 & 1999.05 .12 & 常緑広葉樹・落葉広葉樹の葉色変化時期 \\
\hline 4 & 1999.06 .14 & 梅雨期, モウソウチクの葉色変化時期 \\
\hline 5 & 1999.11 .05 & 落葉広葉樹の紅葉開始時期 \\
\hline 6 & 1999.11 .22 & 落葉広葉樹の紅葉伸展時期 \\
\hline 7 & 1999.12 .08 & 落葉広葉樹の紅葉・黄葉最盛時期 \\
\hline 8 & 2000.02 .18 & 落葉期・スギの褐変時期 \\
\hline
\end{tabular}

真測量用カメラ（Leica 社製 RC-30）を使用した。 対象とした里山は，常緑広葉樹を主体に落葉広葉樹 が混在しているため, カラ一航空写真撮影は, 春季の 常緑広葉樹の開花や新葉の時期，秋季～晚秋季の落葉 広葉樹の紅葉・黄葉時期，などを主体に，そのほか梅 雨期や厳冬期にも撮影した(表 1 )。ただし，夏季は葉 色変化も安定し，常緑広葉樹と落葉広葉樹のそれぞれ の葉色にそれほど変化が生じないため, 撮影は実施し ていない。

多重オルソフォト画像の作成にあたっては，上記の カラー航空写真のネガフィルムを用いて，地上解像度 約 $20 \mathrm{~cm}$ を 1 画素とするデジタル画像デー夕に変換 し, 解析用には 1 画素 $1 \mathrm{~m}$ 四方の画像デー夕を使用し

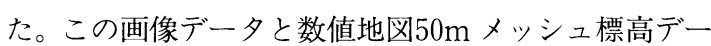
夕を用いて各時期のオルソフォト画像を作成した。こ のうち，撮影中心に近い $100 \times 100$ 画素の範囲を樹冠円 抽出の対象領域とした（図 2 参照）。

対象領域の高木層をみると, 四 2 (C)の画像中央部 (緑 色の箇所に直径 $20 \mathrm{~m}$ の円形の調查区を設定）は，タブ ノキ,ノグルミが優占する樹高 $8 \sim 13 \mathrm{~m}$, 平均胸高直径 $27 \mathrm{~cm}$, 高木本数 13 本からなる傾斜約 $38^{\circ} の$ 平滑斜面上 の林分である。図 2 (C)の画像左下（黄土色の箇所に直 径 $20 \mathrm{~m}$ の円形の調査区を設定）の高木層は，スダジイ が優占する樹高 $15 \sim 16 \mathrm{~m}$, 平均胸高直径 $36 \mathrm{~cm}$, 高木本

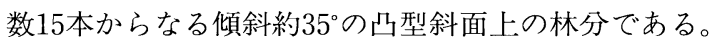
なお，図 2 (C)の画像右端と右下角の樹林はスギ人工林 で，樹高 $17 \mathrm{~m}$ ，平均胸高直径 $27 \mathrm{~cm}$ である。

また，多重オルソフォト画像間の色調を相対的に比 較できるようにできるだけ統一し，相互の画像上での 樹葉の葉色変化を把握しやすいように処理した。この 相対的な色調処理にあたっては，8時期の画像の色調 


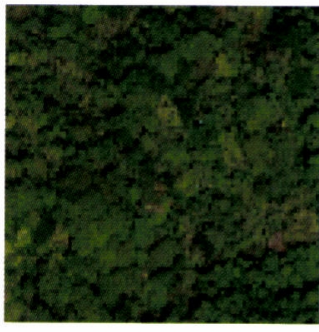

(A) 1999年 4 月 8 日

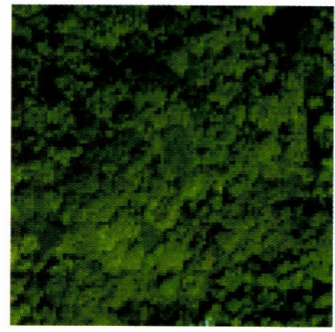

(E) 11 月 5 日

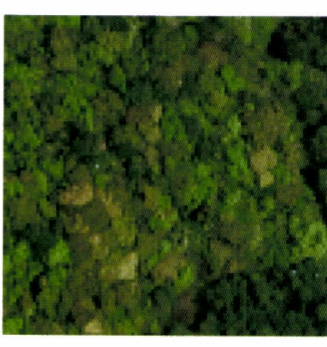

(B) 4 月27日

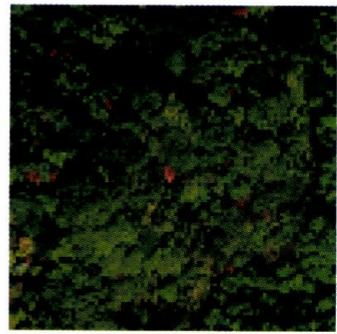

(F) 11 月22日

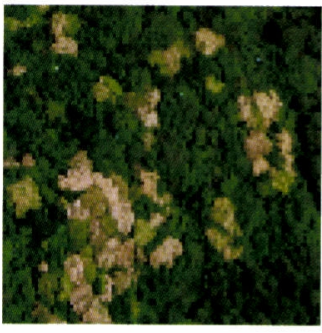

(C) 5 月 12 日

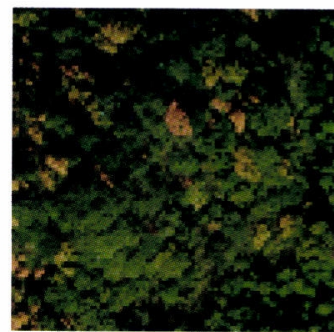

(G) 12 月 8 日

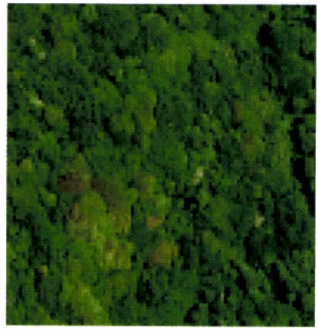

(D) 6 月14日

図 2 多重オルソフォト画像の例

(100画素 $\times 100$ 画素， 1 画素 $1 \mathrm{~m}$ の解像度)

表 21999 年 4 月 8 日を基準とした場合の相対的な色調補 正のための相関係数

\begin{tabular}{|c|c|c|c|}
\hline 撮影年月日 & $\mathrm{R}$ 值 & $\mathrm{G}$ 值 & $\mathrm{B}$ 值 \\
\hline 1999.04 .27 & 0.9469 & 0.9201 & 0.9139 \\
\hline 1999.05 .12 & 0.9354 & 0.8971 & 0.9002 \\
\hline 1999.06 .14 & 0.9613 & 0.9439 & 0.9314 \\
\hline 1999.11 .05 & 0.9788 & 0.9781 & 0.9758 \\
\hline 1999.11 .22 & 0.9262 & 0.9253 & 0.9235 \\
\hline 1999.12 .08 & 0.9366 & 0.9355 & 0.9404 \\
\hline 2000.02 .18 & 0.9548 & 0.9415 & 0.9409 \\
\hline
\end{tabular}

が相対的に比較できることを目的としたため各画像上 で，その形状と色調とが明瞭に識別できる地物（例之 ば赤色・青色・白色の屋根, 黑色のビニールハウスな ど)の領域をそれぞれ30筒所抽出し, RGB 值の平均值 と標準偏差を求めた。1999年 4 月 8 日撮影時点（最初 のカラー航空写真撮影日)の RGB 值を基準に, 他の 7 時期分の RGB 值との相関係数を求めた（表 2 )。これ らの值にしたがって各時期の RGB 值を補正し，4月 8 日時点を基準とした場合の色調に他の 7 時期分の RGB 值を整合させた。

\section{3. 多重オルソフォト画像を用いた樹冠円 抽出のための提案手法}

本研究では, 多重オルソフォト画像を用いて, 単木 単位で樹冠部に円を近似し，樹冠円を抽出する手法を 提案している。この手法では, 多時期のオルソフォト 画像を用いているため, 1 時期のオルソフォト画像を 用いた樹冠円の抽出の場合に比較して, 画像上の陰影 による樹冠円の分断が軽減できること, 季節的な樹葉 の葉色変化を情報として加味しながら，樹冠円をより 高精度に抽出できる点が大きな特色である。

多重オルソフォト画像を用いた樹冠円抽出の手順を 困 1 に示す。その手順は次の通りである。

(1) 多重オルソフォト画像を構成する各画像で樹冠円 の半径を推定する。

（2）上記の処理によって，各画素について画像枚数分 の半径の推定值が得られるので，そのなかでの中央 值（值の大きさの順に並べたときに中央にある值） をその画素での半径の推定值とする。

（3）半径が大きい樹冠円から順に抽出していき, 抽出 した樹冠円に含まれる小さい樹冠円は除去する。

上記の(2)において，中央值を選択することによって 大きすぎたり，小さすぎたりする半径を除外すること 
ができ，それによって樹冠円半径の推定精度が向上す る。

提案手法の具体的な内容は次の通りである。 $m$ 枚のオルソフォト画像からなる多重オルソフォ 卜画像を $f=\left[f^{(i)}\right](i=1, \ldots, m)$ とし, $i$ 番目の画像 $f^{(i)}$ の第 $j$ 画素の RGB 值をそれぞれ $f_{R j}^{(i)}, f_{G j}^{(i)}, f_{B j}^{(i)}$ とする。 各画像 $i$ の画素数は $n(j=1, \ldots, n)$ とする。まず各画像 をメジアンフィルタで平滑化する。フィルタは RGB の各成分に個別にかける。平滑化した多重オルソフォ 卜画像を $\hat{f}$ とする。次に各画像 $i$ の各画素 $j$ を樹冠円 の中心とするときの樹冠円の半径 $r_{j}^{(i)}$ を全ての $(i, j)$ $(i=1, \ldots, m ; j=1, \ldots, n)$ について計算する。 $r_{j}^{(i)}$ の計算 方法は次の通りである。

Step 1 : 半径の初期值を $r=1$ とする。

Step 2 : 画素 $j$ を中心する半径 $r$ のに含まれる

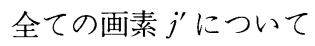

$\max _{X \in\{R, G, B\}}\left\{\hat{f}_{X j^{\prime}}^{(i)}-\hat{f}_{X j}^{(i)}\right\} \leq T_{j^{\prime}}^{(i)}$

かつ

$\max _{X \in\{R, G, B\}}\left\{\hat{f}_{X j}^{(i)}-\hat{f}_{X j^{j}}^{(i)}\right\} \leq t_{j^{\prime}}^{(i)}$

なら Step 3 に進み，その他は Step 4 に進む。

Step 3:r $r+1$ と更新して Step 2 に戻る。

Step $4: r_{j}^{(i)}=r-1$ として終了する。

式(1)は円内の輝度值の最大值に関する制約であり, 式 (2)は最小值に関する制約である。 $T_{j^{\prime}}^{(i)}, t_{j^{\prime}}^{(i)}$ はそれぞれ

$T_{j^{\prime}}^{(i)}=T_{0}\left(1+\tilde{d}_{j^{\prime}}^{(i)}\right)$

$t_{j^{\prime}}^{(i)}=t_{0}\left(1+\widetilde{d}_{j^{\prime}}^{(i)}\right)$

で計算される。ここで $T_{0}, t_{0}$ は予め設定する正定数で あり, $\widetilde{d}_{j^{\prime}}^{(i)}$ は正規化局所フラクタル次元 (小村ら, 2003) である。局所フラクタル次元は樹冠内部で大きな值と なることが知られている(小村ら，2003)。これは樹冠 内部の枝葉が作る細かな陰影がフラクタル性をもつこ とによる。式(3)，式(4)のようにしてフラクタル次元が 高い画素で $T_{j^{\prime}}^{(i)}$, $t_{j^{\prime}}^{(i)}$ の值を大きくすると, 樹冠内部の 細かな陰影を樹冠の境界と䛊る可能性が低くなる。 $\tilde{d}_{j^{\prime}}^{(i)}$ の計算方法については付録を参照されたい。

以上の計算で, 各 $(i, j)$ について $r_{j}^{(i)}$ の値が求まる。 すなわち各画素 $j$ について $m$ 個の半径の推定值 $r_{j}^{(i)}$ $(i=1, \ldots, m)$ が得られる。しかし, この中には樹冠内の 細かな影の影響で半径を過小評価したものや，隣接す
る樹冠との色変化が少ないために半径を過大評価した ものが含まれる可能性がある。このような誤ったデー 夕を排除するために各画素 $j$ で半径推定值の中央値

$r_{j}^{\text {med }}=\underset{i \in\{1, \ldots, m\}}{\operatorname{median}}\left\{r_{j}^{(i)}\right\}$

を選択する。ここで median は中央值を選択すること を表す。

最後に以下の手順で重複した樹冠円を除去する。

Step $1: r_{j}^{\text {med }}>0$ である画素の集合を $S_{0}=\left\{j \mid r_{j}^{\text {med }}>0\right\}$ とし, 出力画素の集合を $S=\phi$ と初期設定す る。

Step $2 ： S_{0}$ に含まれる画素の中で $r_{j}^{\text {med }}$ が最大の画素 を選び，それを $j^{*}$ とする。 $j^{*}$ を $S_{0}$ から $S$ に 移す。

Step 3 : 画素 $j^{*}$ と $j^{\prime}$ の間の距離を $D_{E}\left(j^{*}, j^{\prime}\right)$ とし, $D_{E}\left(j^{*}, j^{\prime}\right) \leq r_{j^{*}}^{\text {med }}$ を満たす $j^{\prime} \in S_{0}$ を全て $S_{0}$ から除去する。

Step $4: S_{0} \neq \phi$ なら Step 2 に戻り，その他は $S$ を出力 して終了する。

以上の手順で得られる $S$ に含まれる各画素 $j$ を中 心とし，それに対応する $r_{j}^{\text {med }}$ を半径として画像上に円 を描くと推定樹冠円の分布が得られる。

\section{4. 提案手法の適用性評価}

ここでは, 前述（2．）の 8 時期分の多重オルソフォ 卜画像のうち，1999年 4 月 8 日，4月27日，5月12日， 6 月 14 日， 11 月 5 日，11月 22 日，12月 8 日の 7 回にわ たって撮影した画像を用いた（ただし，2000年 2 月 18 日撮影の画像は落葉後のため使用せず)。図 2 には, 本 提案手法の適用性を評価した検証箇所を示す。各画像 のサイズは $100 \times 100$ 画像で, 空間解像度は 1 画素 $1 \mathrm{~m}$ である。輝度分解能は RGB それぞれ 8 ビットである。

評価用の検証画像は, 四 2 の画像を用いて目視判読 によって単木単位に樹冠円を識別し, 識別した樹冠円 の中心に白点を付け，これを正解とした(図 3 )。落葉 樹林は春先の開葉期および秋の落葉期には葉色に特色 があり，判読が比較的容易である。しかし，常緑広葉 樹林は葉色にあまり差がなく, 落葉樹林に比べて判読 が難しい。現地での平均的な樹冠円の観察結果等を参 考に判読した。

ここで，目視抽出した樹冠中心画素の集合を $S_{L}$ と し，樹冠円抽出アルゴリズムによって自動抽出した樹 


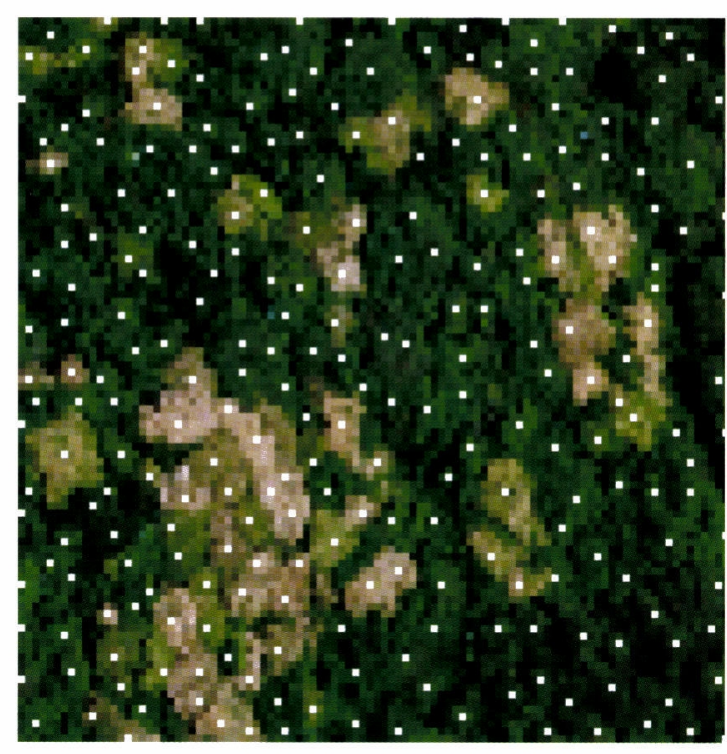

図 3 目視判読による評価検証用の樹冠中心

冠门の中心画素の集合を $S_{T}$ とし， $S_{L}$ と $S_{T}$ の誤差を

$\frac{\sum_{j \in S_{L}} \min _{j^{\prime} \in S_{T}} D_{E}\left(j, j^{\prime}\right)}{\sum_{j \in S_{L}} 1}+\frac{\sum_{j \in S_{T}} \min _{j^{\prime} \in S_{L}} D_{E}\left(j, j^{\prime}\right)}{\sum_{j \in S_{T}} 1}$

によって評価する。これは 2 つの集合 $S_{L}, S_{T}$ 間で各樹 冠円中心に最も近い樹冠円中心を他方の集合から選 び，その距離を全ての樹冠円で平均したものである。 式(6)の值は $S_{L}=S_{T}$ のときに0 となり，それ以外では 正の值となる。図 4 に誤差評価の結果を示す。

図 4 には8つの点がプロットされており，同図中で 左から 7 つの点は, 前述までの 7 時期分（1999年 4 月

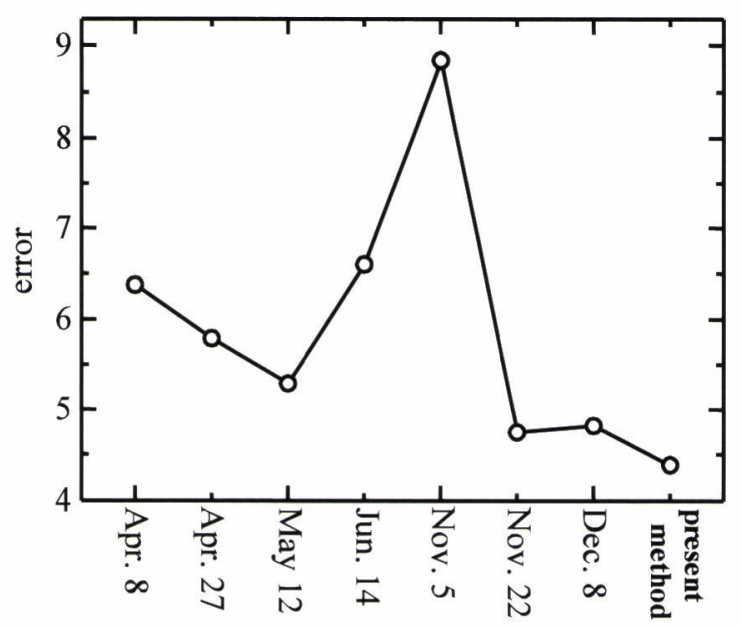

図 4 樹冠円の抽出誤差

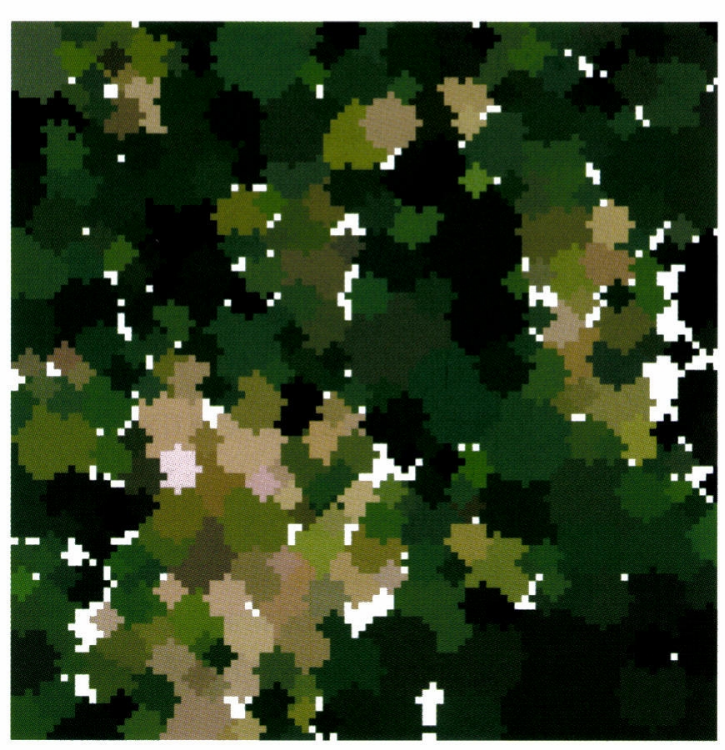

図 5 本手法で抽出された樹冠円

(図中で白色箇所は，どの樹冠円にも属さない箇所を表す)

8 日〜 12 月 8 日までの 7 時期に撮影）の各画像（困 1 (A) (G)の各画像) から個別に樹冠円を抽出したときの 誤差を示している。左から 5 つ目の点(11月 5 日撮影) のように撮影時期によっては, 䛊差が大きくなる場合 があることが分かる。右端の点は本研究による提案手 法での䛊差であり，各画像から個別に抽出した場合よ りも䛊差が小さくなっている。これは樹冠円抽出に用 いる画像の枚数を增やすことによって抽出の精度を向 上させ得ることを示している。提案手法によって抽出 された樹冠円の分布を図 5 に示寸。

樹冠円の色には図 2 (C)の右上の画像の色を用い, 各 樹冠円は中心画素の色で着色した。このように多重才 ルソフォト画像を用いることによって，1時期分の画 像だけを用いる場合よりも目視抽出に近い樹冠円抽出 が行えることが確認された。提案手法は, 特定の森林 域を複数の時期にわたって撮影可能な場合に有効であ ると考えられる。なおメジアンフィルタのウィンドウ サイズは $3 \times 3$ 画素とし, 式(3), 式(4)の定数は $T_{0}=20$, $t_{0}=30$ とした。

\section{5.おわりに}

多重オルソフォト画像から樹冠円を抽出する方法を 提案し， 1 時期の画像から抽出する従来手法よりも目 視抽出に近い結果が得られることを検証で確認でき 
た。ただし，樹冠円抽出に適した撮影時期の特定など が課題となる。

今後, 多重オルソフォト画像と航空機レーザスキャ ナデータとを併用した樹冠円抽出手法の確立や林相夕 イプ別（例えば，今回のような多種多様な樹種から構 成される里山林以外にも, 常緑広葉樹から形成される 自然林やスギ・ヒノキ人工林など）での適用性を検証 したいと考えている。

（受付日2006.2.23，受理日2006.5.12）

\section{参考文献}

朝廣和夫, 井上光平, 上原三知, 重松敏則, 瀬戸島政 博, 2003. 空撮画像の同質領域判定による九州北部 里山林の樹冠抽出に関する研究, 日本造園学会誌, 66(5), pp.499-502.

小熊宏之, 山形与志樹, 2000. リモートセンシングデー 夕を用いた森林樹冠率の推定（京都議定書対応のた めのリモートセンシング技術の確立), 写真測量とリ モートセンシング, 39(2), pp.82-89.

小村良太郎, 久保 守, 村本健一郎, 2003. 空撮画像 を用いた局所フラクタル次元による樹冠解析, 写真 測量とリモートセンシング，42(4)，pp.27-37. 瀬戸島政博, 赤松幸生, 福井裕子, 今井靖晃, 朝廣和 夫, 重松敏則, 2001. 年間にわたる時系列なカラー 航空写真データからみた里山林の代表的な常緑広葉 樹の色調変化，環境情報科学論文集，15, pp.31-36. 瀬戸島政博, 赤松幸生, 今井靖晃, 重松敏則, 朝廣和 夫, 児玉滋彦, 2002. カラ一航空写真上の季節の色 調変化からみた里山構成樹種の識別に関する研究, ランドスケープ研究，65(5), pp.679-684.

瀬戸島政博, 今井靖晃, 船橋 学, 勝木俊雄, 2005 . 航空デー夕上の色調変化および落葉推移に基づく混 交林の代表的な樹種の区分, ランドスケープ研究, 68(5), pp.931-936.

重松敏則, 朝廣和夫, 瀬戸島政博, 牧田史子, 1997. 現存植生環境動態図の作成とその活用に関する基礎 的研究, 日本造園学会誌, 60(5), pp.527-530.

Song, C., Woodcock, C.E., 2003. Estimating tree crown size from multiresolution remotely sensed imagery, Photogrammetric Engineering \& Remote Sensing, 69(11), pp.1263-1270.
中山 寛, 曾根光男, 高木幹雄, 1989. フラクタル次 元と低次統計量とを用いた気象衛星 NOAA 画像の 解析とその評価, 情報処理学会論文誌, 30(1), pp. 91-100.

\section{補足 局所フラクタル次元の計算}

本節では，局所フラクタル次元の計算方法を概説す る。詳しくは小村ら（2003）や中山ら（1989）を参照 されたい。まず多重オルソフォト画像を構成する各画 像 $i$ の各画素 $j$ を $g_{j}^{(i)}=0.299 f_{R j}^{(i)}+0.587 f_{G j}^{(i)}+0.114$ $f_{B j}^{(i)}$ によってモノクロにする。局所フラクタル次元の 計算は各画像 $i て ゙$ 独立に行えるので, 以下では記述を 簡単にするために $i$ は省略することにする。画素 $j$ を 中心とする直径 $D$ の円を考之，その円に含まれる画素 の集合を $C_{j}^{(D)}$ とする。また $C_{j}^{(D)}$ に含まれる各画素 $j^{\prime} \in C_{j}^{(D)}$ を中心とする直径 $d$ の円を考之，その円に含 まれる画素の集合を $C_{j j^{\prime}}^{(d)}$ とする。

$g_{j j^{\prime}}^{\max }(d)=\max _{j^{\prime \prime} \in C j_{j} g^{\prime}}\left\{g_{j j^{\prime}}\right\}$

$g_{j j^{\prime}}^{\min }(d)=\min _{j^{\prime \prime} \in C_{j j^{\prime}}}\left\{g_{j^{\prime \prime}}\right\}$

として

$v_{j j^{\prime}}(d)=\left\lfloor\left[g_{j j^{\prime}}^{\max }(d)-g_{j j^{\prime}}^{\min }\right] / d\right\rfloor+1$

とする。更に

$V_{j}(d)=\left(\frac{D_{2}}{d_{2}}\right) \frac{\sum_{j^{\prime} \in C_{j}^{\prime j}, j^{\prime}} v_{j^{\prime}}(d)}{\sum_{j^{\prime} \in C_{j}^{(j)}} 1}$

とする。 $D=25$ とし,$d$ は $d=4,8,16$ と変化させて 3 つの点 $\left(x_{d}, y_{d}\right)=\left(\log d, \log V_{j}(d)\right)(d=4,8,16)$ を求 め, この 3 点への回帰直線の傾き

$a=\frac{\left(\sum_{d} x_{d} y_{d}\right)\left(\sum_{d} 1\right)-\left(\sum_{d} x_{d}\right)\left(\sum_{d} y_{d}\right)}{\left(\sum_{d} x_{d}^{2}\right)\left(\sum_{d} 1\right)-\left(\sum_{d} x_{d}\right)^{2}}$

より, 局所フラクタル次元を $\hat{d}_{j}=-a$ とする。 $\hat{d}^{\max }=$ $\max _{j}\left\{\hat{d}_{j}\right\}, \hat{d}^{\min }=\min _{j}\left\{\hat{d}_{j}\right\}$ とおいて

$\tilde{d}_{j}=\frac{\hat{d}_{j}-\hat{d}^{\min }}{\hat{d}^{\max }-\hat{d}^{\min }}$

としたものが正規化局所フラクタル次元である。 